\title{
JM
}

Volume 5 No. 1 (Juli 2017)

(C) The Author(s)

\section{PENGARUH PEMBERIAN EKSTRAK BIJI MANJAKANI (QUERCUS INFECTORIA GALL)TERHADAP BAKTERI VAGINOSIS DAN CANDIDA PENYEBAB KEPUTIHAN (LEUKORRHEA)}

\section{EFFECT OF GIVING OF MANJAKANI EXTRACT (QUERCUS INFECTORIA GALL) ON VAGINOSIS AND CANDIDA BACTERIA OF LEISURE (LEUKORRHEA)}

\author{
DARA HIMALAYA \\ PROGRAM STUDI KEBIDANAN FMIPA UNIB
}

\begin{abstract}
ABSTRAK
Keputihan merupakan hal yang kerap dikeluhkan seorang wanita. Lebih dari $75 \%$ wanita dewasa pernah mengalami keputihan sepanjang siklus hidupnya. Penggunaan antibiotik secara sembarangan dan meluasnya penggunaan obat antimikroba untuk terapi atau profilaksis dalam pengobatan penyakit menular telah menyebabkan peningkatan jumlah resistensi mikroba, sehingga mengharuskan kita mencari alternative obat-obatan untuk antimikroba baru, zat-zat ini dapat berasal dari sumber-sumber alam termasuk tanaman Manjakani. Manjakani (Quercus infectoria Gall) tanaman tradisional yang diyakini memiliki banyak manfaat besar bagi kesehatan organ intim wanita. Secara Farmakologi manjakani diklaim memiliki berbagai aktivitas biologis seperti efek astringent, anti diabetes, anti tremorine, anestesilokal, antipiretik, anti-inflamasi, anti bakteri, anti jamur, anti virus dan banyak lagi. Skrining fito kimia manjakan menunjukkan adanya kandungan fenol, flavonoid, steroid, triterpen, tanin, saponin dan alkaloid serta zat lainnya. Manjakani telah dilaporkan dapat juga digunakan untuk penyembuhan luka, sebagai local agen anestesi pada periode pasca-partum, pengobatan dan pencegahan keputihan, pengobatan pada radang gigi dan mulut serta kesehatan tulang. Metode yang digunakan adalah studi tinjauan literatur (literature review) yang mencoba menggali bagaimana ektrak biji manjakani dapat mengatasi mikroba penyebab keputihan. Sumber untuk melakukan tinjauan literatur ini meliputi studi pencarian sistematis database terkomputerisasi (Pubmed, Hindawi, Google Scholer) dalam bentuk jurnal penelitian yang berjumlah 26 jurnal. Hasil penelitian menunjukkan adanya pengaruh ektrak manjakani terhadap penghambatan pertumbuhan mikroba akibat keputihan.
\end{abstract}

Kata kunci: leuchorrhea, manjakani (Quercus Infectoria Gall)

\begin{abstract}
Leisure is something that is often complained of a woman. More than $75 \%$ of adult women have experienced about leisure throughout their life cycle. The use of antibiotics carelessly and the widespread use of antimicrobial drugs for therapies or prophylaxis in the treatment of infectious diseases has led to an increase in the number of microbial resistance, thus requiring us to find alternative medicines for new antimicrobial, this can come from natural sources including the Manjakani plant. Manjakani (Quercus infectoria Gall) a traditional plant that is believed to have many great benefits for the health of female sex organs. Pharmacology manjakani claimed to have a variety of biological activities such as astringent effects, anti
\end{abstract}


diabetic, anti tremorine, anestesilokal, antipyretic, anti-inflammatory, anti bacterial, anti-fungal, anti-virus and more. Screening of phytochemical chemicals shows the presence of phenol, flavonoids, steroids, triterpenes, tannins, saponins and alkaloids and other substances. Manjakani has been reported can also be used for wound healing, as local anesthetic agents in the post-partum period, treatment and prevention of leisure, treatment of dental and mouth and bone health. The method used is literature review (literature review) which tries to dig how manjakani extract can overcome the microbial cause of leucorrhoea. Sources for reviewing this literature include a systematic search of a computerized database (Pubmed, Hindawi, Google Scholer) in the form of a research journal of 26 journals. The results showed the influence of manjakani extract on the inhibition of microbial growth due to vaginal discharge.

Keywords: leuchorrhea, manjakani (Quercus Infectoria Gall)

\section{PENDAHULUAN}

Keputihan merupakan hal yang selalu menarik untuk diteliti dan dipelajari, hal ini karena masih tingginya angka kejadian dan efek yang ditimbulkan oleh keputihan, serta beban biaya yang cukup besar bila terjadi dampak lebih lanjut. Kejadian keputihan di selatan Asia Timur terdapat sekitar seperempat dari semua wanita pernah mengalami keluhan keputihan. ${ }^{1}$ Data penelitian tentang kesehatan reproduksi wanita menunjukkan $75 \%$ wanita di dunia pasti menderita keputihan, paling tidak sekali seumur hidup dan $45 \%$ diantaranya dapat mengalami dua kali atau lebih. ${ }^{2,3}$

Indonesia merupakan negara beriklim tropis yang menyebabkan udara cendrung panas dan lembab, sehingga sering membuat banyak berkeringat, terutama di bagian tubuh yang tertutup dan di daerah lipatan kulit, salah satunya adalah daerah organ genitalia,selain itu posisi anatomis vagina yang berada berdekatan antara uretra dan anus menyebabkan kuman penyakit seperti jamur, bakteri, parasit, maupun virus mudah masuk ke liang vagina. Kondisi ini menyebabkan mikroorganisme patogen menjadi mudah menginfeksi dan bekembangbiak, sehingga terjadilah keputihan patologis. ${ }^{4}$ Berdasarkan data Survey Demokgrafi Kesehatan Indonesia (SDKI) tahun 2012 menyatakan angka kejadian keputihan pathologis pada wanita usia antara 15-49 tahun adalah rata-rata sebesar $11,3 \%$. Data tersebut menyatakan cukup tingginya angka kejadian keputihan di Indonesia pada wanita usia reproduktif. ${ }^{5}$
Keputihan akan terkait dengan peningkatan $\mathrm{pH}$ vagina dan penggantian bakteri fisiologis Lactobacillia chidophilus vagina dengan bakteri patogen vaginalis. Keputihan merupakan masalah yang perlu diperhatikan secara khusus bagi kesehatan masyarakat karena tingginya beban reproduksi, kehamilan dengan morbiditas, infertilitas, meningkatkan keretanan terhadap infeksi menular seksual (IMS) termasuk penularan HIV menjadi dua kali lipat. Apabila keputihan tidak normal tidak ditangani dan diobati, akibatnya infeksi bisa menjalar masuk ke dalam rahim, saluran telur, hingga menginfeksi ovarium. Kondisi ini bisa merusak organ reproduksi bagian dalam dan hal inilah yang dapat mengakibatkan infertilitas, dan pada wanita hamil dapat menyebabkan kelahiran premature, BBLR, KPD dan lainnya. Sehingga kita harus mewaspadai munculnya gejala-gejala keputihan yang tidak normal. Karena itu dalam menjaga pola hidup sehat dan kebersihan diri sangatlah penting untuk mencegah terjadinya keputihan. ${ }^{6}$

Pengobatan keputihan yaitu berdasarkan gejala klinis dan tanda-tanda yang didukung dengan temuan uji laboratorium, gejala klinis ini akan berbeda - beda sesuai dengan spesifikasi etiologi keputihannya yang bervariasi. Penatalaksanaan secara medis untuk wanita yang mengalami keputihan patologis dari jenis bakteri, protozoa, jamur, dan virus akan diberikan terapi antibiotic seperti golongan metronidazole, clindamycin atau jenis lain yang sesuai menjadi pilihannya. $^{7}$ 
Pengobatan secara medis banyak mengalami keluhan seperti terjadinya resistensi, recurrent atau pengulangan kembali kejadian infeksi saluran reproduksi oleh keputihan, perlu adanya pengawsan dokter, serta efek samping toksik lainnya. Untuk itu dibutuhkan pengobatan alternative yang dapat membantu bahkan dapat menggantikan penggunaan bahan obat-obatan sintestis dengan yang lebih alami. Obat tradisional herbal yang berasal dari tumbuhan dan bahan - bahan alam murni, memiliki efek samping, tingkat bahaya dan risiko yang jauh lebih rendah dibandingkan dengan obat kimia (Muhlisah, 2005). Salah satu tanaman potensial yang terdapat di Indonesia dapat dimanfaatkan untuk pengobatan keputihan diantaranya yaitu: biji manjakani (quercus infectory gall). Hal ini dikarenakan manjakani (quercus infectory gall) mengandung senyawa metabolit sekunder yang diduga mempunyai efek antibakteri. Kandungan fitokimia biji manjakani mampu menghambat dan membunuh kuman - kuman atau mikroorganisme yang bisa menyebabkan penyakit pada manusia. (Quercus infectoria Gall). ${ }^{8}$

\section{METODE PENELITIAN}

Metode yang digunakan adalah studi tinjauan literatur (literature review) yang mencoba menggali bagaimana biji manjakani yang dapat mencegah dan mengobati keputihan. Sumber untuk melakukan tinjauan literatur ini meliputi studi pencarian sistematis database terkomputerisasi (Pubmed, Hindawi, Google Scholer) dalam bentuk jurnal penelitian yang berjumlah 26 jurnal. Penulisan artikel ilmiah ini menggunakan penulisan daftar pustaka vancouver.

\section{HASIL PENELITIAN}

\section{Keputihan (Leuchorrhea)}

Vagina dilapisi oleh epitel barlapis gepeng. Bersama flora normal vagina, lapisan tersebut bertanggung jawab dalam mempertahankan kelembaban vagina, dan berperan dalam mekanisme pertahanan nonspesifik vagina terhadap infeksi mikroorganisme. Vagina dapat mensekresi glikogen yang kemudian diubah oleh flora normal menjadi asam laktat. Mekanisme ini menyebabkan keasaman vagina stabil pada $\mathrm{pH}$ 3,8-4,5. Keasaman vagina tersebut merupakan salah satu mekanisme proteksi terhadap infeksi, karena menyebabkan mikroorganisme pathogen tidak dapat hidup pada lingkungan tersebut. ${ }^{6}$

Keputihan akan terkait dengan peningkatan $\mathrm{pH}$ vagina dan penggantian bakteri fisiologis Lactobacilli vagina dengan bakteri pathogen vaginalis. Keputihan adalah masalah yang perlu diperhatikan secara khusus bagi kesehatan masyarakat karena tingginya beban reproduksi, kehamilan dengan morbiditas, infertilitas, meningkatkan keretanan terhadap infeksi menular seksual (IMS) termasuk penularan HIV menjadi dua kali lipat. Apabila keputihan tidak normal dibiarkan saja tanpa diobati, akibatnya infeksi bisa menjalar, masuk ke dalam rahim, saluran telur, dan bisa juga sampai menginfeksi ovarium. $^{7}$

Kondisi ini bisa merusak organ reproduksi bagian dalam dan hal inilah yang dapat mengakibatkan infertilitas, dan pada wanita hamil dapat menyebabkan kelahiran premature, BBLR, KPD dan lainnya. Sehingga kita harus mewaspadai munculnya gejala-gejala keputihan yang tidak normal. Karena itu dalam menjaga pola hidup sehat dan kebersihan diri sangatlah penting untuk mencegah terjadinya keputihan. ${ }^{7}$

Keputihan merupakan suatu keadaan dimana terjadi peningkatan produksi secret oleh serviks uteri, sehingga kemudian keluar melalui vagina. Keputihan terbagi menjadi dua jenis, yaitu keputihan fisiologis dan patologis.

\section{Keputihan fisologis}

Keputihan fisiologis ditandai dengan secret vagina yang berwarna bening, tidak 
menimbulkan bau yang menyengat, iritasi, maupun rasa neyri.

Keputihan fisiologis dapat ditemukan pada beberapa keadaan, yaitu bayi baru lahir (BBL) sampai umur kira-kira 10 hari, waktu sekitar menstruasi, hasrat seksual, siklus haid, kehamilan, penggunaan pil kontrasepsi, dan stress.

\section{Keputihan patologis}

Keputihan patologis biasanya ditandai dengan secret vagina yang berwarna keruh atau kuning kehijauan, berbau tidak sedap, disertai lesi atau iritasi vagina, dyspareunia, gatal, dan perdarahan. Penderita juga dapat mengeluhkan sistitis yang berupa disuria ekternal akibat lesi vulva.

Berdasarkan mekanisme terjadinya, keputihan patologis dapat dibedakan menjadi keputihan patologis yang infeksius dan noninfeksius. Penyebab keputihan infeksius adalah bakteri vaginosis (BV) yang umumnya menjadi etiologi sebesar $90 \%$ dari semua etiologi keputihan sebagian besar bakteri ini seprti Gardanerrella vaginalis, , jamur Candida sp. terutama spesies Candida albicansProtozoa : Trichomonas vaginalis, bakteri Chlamidia trachomatis, Neisseria gonorrhoea, dan Gonococcus. Penyebeb karena Virus : Herpes virus dan Human Papiloma Virus dan Keputihan patologis yang non-infeksius disebabkan oleh polip serviks, neoplasma serviks, materi yang teringgal (misalnya tampon atau pasca terminasi kehamilan), trauma, vaginitis atrofik, reaksi alergi (misalnya akibat pembasuh vagina), dan membersihkan vagina degan sabun, terutam produk anti bakteri, dan menimbulkan bau tak sedap. ${ }^{2,3}$

\section{PEMBAHASAN}

\section{Manjakani (Quercus Infectoria Gall)}

Manjakani adalah tumbuhan yang cukup banyak tumbuh di Indonesia yang juga banyak ditemukan di Turki, Syiria, Persia, Siprus, dan Yunani. Biji manjakani berasal dari pohon manjakani atau dikenal dengan pohon oak. Pohon manjakani dikenal pula dengan oak galls dan mecca majakan. ${ }^{8}$

Tumbuhan ini menghasilkan biji yang muncul pada ranting muda atau daun sebagai reaksi akibat tusukan serangga Cynips gallae tinctoria, tusukan ini akan menyebabkan kulit batang bertunas dan mengeluarkan larva yang merangsang pembentukan biji. Manjakani merupakan salah satu obat yang paling populer di Asia. ${ }^{19,20}$

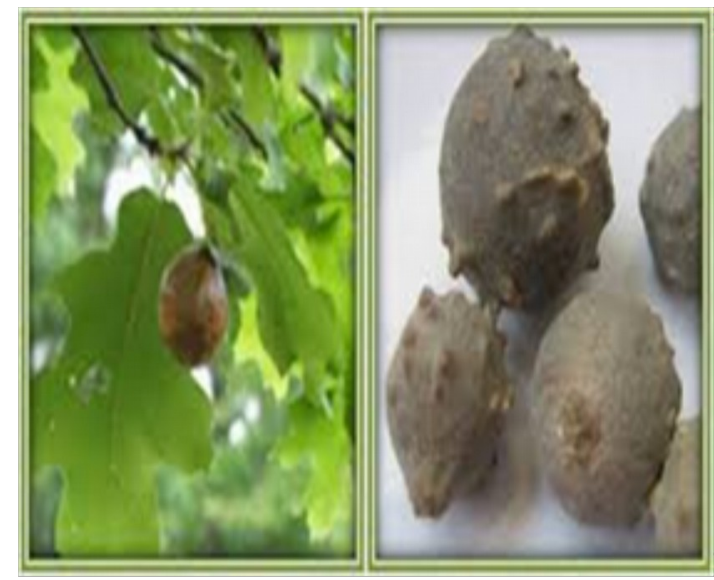

Gambar:Manjakani (Quercus Infectoria Gall) Sumber: www.google.com

Pemeriksaan kandungan mineral penting biji manjakani seperti kalsium, magnesium, fosfor, oksigen, kalium, aluminium, karbon, seng, besi, mangan, nikel, dan silika dapat menjadi sumber yang baik untuk mengobati sejumlah penyakit yang terutama disebabkan dengan kekurangan mineral tersebut, misalnya osteoporosis yang merupakan kondisi yang disebabkan oleh defisiensi kalsium dan beberapa penyakit lainnya. ${ }^{19,20}$

Skrining fitokimia menunjukkan adanya kandungan fenol, flavonoid, steroid, triterpen, tanin, saponin dan alkaloid serta zat lainnya pada manjakani telah dilaporkan memiliki peran sebagai antibakteri, antijamur, antiinflamasi, antioksidan dan untuk penyembuhan luka. Manjakani juga telah digunakan sebagai lokal agen anestesi pada periode pasca-partum. ${ }^{8,19,20}$

Manjakani mengandung sekitar 50-70\% 
tanin, sejumlah kecil asam galat gratis dan ellagic Asam yang telah terbukti menjadi aktif senyawa yang bertanggung jawab untuk anti bakteri.

Manfaat penggunaan bahan olahan biji manjakani telah diteliti oleh para peneliti dan dilaporkan memiliki kemampuan menghambat pertumbuhan bakteri dan jamur penyebab keputihan baik pada pengguna kontrasepsi hormonal, kontrasepsi dalam Rahim (AKDR), pada ibu hamil dan pada wanita usia repoduktif lainnya yang mengalami keluhan keputihan. Hasil penelitian didapatkan bahwa terdapat rata-rata penurunan jumlah koloni bakteri (99\%), penurunan jumlah koloni jamur sebesar (99\%), dan penurunan keluhan keputihan $60 \%{ }^{22-25}$

Mekanisme kerja fitokimia biji manjakani adalah menghambat pertumbuhan dan dapat membunuh bakteri, melalui cara membentuk molekul kompleks fitokimia dan mikroba yang mempengaruhi membran mikroorganisme, mengurangi konsentrasi zat besi dalam transportasi sel dengan berbagai ikatan nitrogen yang mengandung kelompok protein, dan mengganggu metabolisme bakteri melalui penghambatan fosforilasi oksidatif, mengganggu pembelahan sel dan mengubah morfologi sel. efek yang signifikan dari toleransi variasi tekanan osmotik yang dimulai dari tahapan sel mengerut, pecah dan mengalami lisis. ${ }^{8,19,20-25}$

Senyawa antijamur bekerja secara bersama-sama membunuh $C$. albicans melalui mekanisme perusakan dinding sel jamur, mempengaruhi sterol membran plasma sel jamur, dan sintesis asam nukleat. Mekanisme penghambatan pertumbuhan jamur oleh adanya senyawa kimia yang merusak struktur dinding sel pada $C$. albicans. Senyawa yang dapat merusak komponen dinding sel jamur diantaranya senyawa tanin dan fenol, tanin telah dibuktikan dapat membentuk kompleks senyawa yang irreversibel dengan prolin (suatu protein lengkap), yang mana ikatan ini mempunyai efek penghambatan sintesis protein untuk pembentukan dinding sel, sedangkan fenol dan saponin bekerja dengan cara merusak dan menembus dinding sel. Akibatnya akan mengalami kerusakan dinding sel dan menyebabkan senyawa antifungi dapat masuk ke dalam tubuh jamur dan merusak komponen yang terdapat di dalam. 22,29,30

Kompleksitas mekanisme kerja fitokimia dalam biji manjakani akan menghambat bahkan dapat membunuh sel bakteri dan jamur, dengan berkurangmya jumlah mikroba koloni bakteri dan jamur patogen, keseimbangan ekosistem vagina dapat terjaga. Kondisi ini mengakibatkan $\mathrm{pH}$ yang rendah $(3,5-4,5)$, yang memungkinkan kelangsungan hidup dan pertumbuhan dari organisme fisiologi dan mencegah mikroba patogen untuk berkembangbiak, dengan begitu maka dapat mengurangi keluhan keputihan yang sangat mengganggu kenyamanan dan kepercayaan diri wanita terhadap kesehatan organ kewanitaannya. $6,10,13$

\section{KESIMPULAN}

Keputihan merupakan hal yang sering dikeluhkan oleh wanita, sebanyak $75 \%$ wanita di dunia pasti menderita keputihan. Keputihan merupakan tanda gejala dari suatu gangguan kesehatan reproduksi wanita sehingga harus segera ditangani dengan tepat. salah satu upaya untuk mengatasi keputihan tersebut dapat menggunakan produk alami yang berasal dari tanaman potensial yang telah diteliti memiliki aktivitas antimikroba.

Dalam beberapa riset, buah majakani banyak bermanfaat bagi kesehatan organ intim karena mengandung beberapa zat fitokimia yang berperan aktif dalam membunuh bakteri dan jamur penyebab keputihan seperti senyawa fenolik, flavonoid dan tanin minyak astrigen dan lainnya yang dapat menekan pertumbuhan mikroba patogen yang dapat menyebabkan keputihan.

\section{DAFTAR PUSTAKA}

Amilah WN, Masrah M., Hasmah A, Izani N.J. In vitro antibacterial activity of 
Quercus infectoria gall extracts against multidrug resistant bacteria. 2014. J Trop Biomed:31(4): Hlm680-688.

Basri DF, Khoiron R. Phsrmacodynamic interaction of quercus infectoria galls extract in combination with vacomycin against MRSA using microdulation checerboard and time-kill assay. J Compl Altr Med.2012:1-7.

Basri DF, Tan, LS, Shafiei Z, Zin NM. In vitro antibacterial activity galls of quercus infectoria olivier against oral pathogens. J Eviden Compl Alt Med.2012:1-6.

BPOM. Acuan sediaan herbal. Jakarta: Direktorat Jendral Pengawasan Obat dan Makanan, Departemen Kesehatan RI; 2011;1(6):7-10.

Cunningham FG, Gant NF, Leveno KJ, Gilstrap LC, Hauth JC, Wenstrom KD.Obtetri Williams. In ; Berek \& Novak's Ciynecolo ry, 21 th ed, Philadephia ; Lippincott William\&Wilkins ; 2007. p 31-62

Departemen Kes RI. Kesehtan remaja.2010, SDKI 2012

Dewiani K. Pengaruh pemberian cebokan rebusan biji manjakani (Quercus infectoria Gall) terhadap jumlah koloni bakteri dan jamur pada akseptor kontrasepsi hormonal yang mengalami keluhan keputihan. J.IJMC.2017

Fredricks DN, Fiedler TL, Marrazzo JM. Molecular Identification of bacteria associated with bacterial vaginosis. J Engl med.2005;353(18):1-13.

Gul S, Qamar H, Jawaid W, Bukhari U, Javed Y. Women facing heavy vaginal discharge (leucorrhea) by virtue of unhealthy life style. $J$ int Reserch phar.2013;4(1):258-61.

Indriana $\mathrm{P}$, Widyawati $\mathrm{W}$ and Armalina D. Hubungan antara terjadinya bakterial vaginosis dengan penggunaan kontrasepsi hormonal: J FK Undip.2016

Kataria U, Siwach S, Chhillar D. Study of the causes of vaginal discharge among sexually active females in age group of 20-45 years: A hospital based study in
B.P.S. Government Medical College for Women, Khanpur Kalan, District Sonipat Harnana India. J Interl Arch Integ Med.2015;2(4):1-4.

Manuaba. Ilmu Kebidanan, Penyakit Kandungan, dan KB.Jakarta:EGC.2010.

Modak T, Arora P, Agnes C, Ray R, Goswami S, Ghosh P, dkk. Diagnosis of bacterial vaginosis in cases of abnormal vaginal discharge: comparison of clinical and microbiological criteria.J Infect Dev Ctries 2011; 5(5):353-360.

Mayasari I, Khuzaiyah S, Krisiyanti R. Karakteristik Wanita dengan Fluor Albus. JIK. 2015;7(1).

Ortiz MI, Bautista EJ, Sánchez BA, Sánchez BA and Escamilla MA. Clinical and microbiological features of vulvovaginitis in Mexican girls. J Obst Gyn.2013;3(02): 243

Pengaruh pemberian cebokan rebusan biji manjakani (Quercus infectoria Gall) terhadap jumlah koloni sptretococcus sp dan escheria colli pada akseptor kontrasepsi dalam Rahim (AKDR) yang mengalami keluhan keputihan. J.IJMC. 2017

Pengaruh pemberian cebokan rebusan biji manjakani (Quercus infectoria Gall) dan sirih merah terhadap jumlah koloni candida albicans pada wanita usia reproduksi yang mengalami keluhan keputihan. J.IJMC.2017

Philip PS, Benjamin AI, Sengupta P. Prevalence of symptoms suggestive of reproductive tract infections/sexually transmitted infections in women in an urban area of Ludhiana. J Sex Transm Dis. 2013;34:83-8.

Rahayu S, Sundari S and Widiyani E. Hubungan lama pemakaian kontrasepsi suntik kombinasi dengan kadar glukosa darah di bpm "e" kecamatan purwosari, pasuruan. J South Asian Mid.2016;1(1): 10-5.

Sari HF. Hubungan Penggunaan dan lama penggunaan jenis kontrasepsi hormonal dengan kejadian keputihan pada akseptor keluarga berencana di wilayah kerja 
puskesmas kartasura sukoharjo.Skripsi FK. IKM UMS.2015.

Sari HF. Hubungan Penggunaan dan lama penggunaan jenis kontrasepsi hormonal dengan kejadian keputihan pada akseptor keluarga berencana di wilayah kerja puskesmas kartasura sukoharjo.Skripsi FK. IKM UMS.2015.

Sherrard J, Donders G, White D, Lead. European (IUSTI/WHO) guideline on the management of vaginal discharge. J Int STD\&AIDS.2011:22:Hal421-429.)

Sherrard J, Donders G, White D, Lead. European (IUSTI/WHO) guideline on the management of vaginal discharge. J Int STD\&AIDS.2011;22:421-29.

Speroff L, Glass RH, Kase NG. Clinical gynecologic endocrinology and infertility. Edisi ke-6;1996.

Utamingtyas F. Pengaruh pemberian cebokan rebusan biji manjakani (Quercus infectoria Gall) terhadap jumlah koloni bakteri dan jamur pada pada ibu hamil TM II yang mengalami keluhan keputihan. J.IJMC.2017

Yanti N, Samingan, Mudatsir. Uji aktivitas anti fungi ekstrak etanol gal manjakani (Quercusinfectoria).J Mahasiswa Pendidikan Biologi.2016;1(1 ):1-9. 